\title{
Racine e Port Royal: um jardim inesquecível
}

Viviane Cunha

Universidade Federal de Minas Gerais

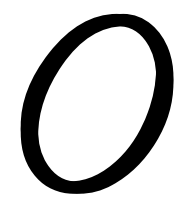

título deste trabalho se justifica, pela relação que teve Jean Racine com Port Royal, no início de sua vida, fato que não deve ser subestimado ou ignorado. Por sua vez, Port Royal foi um ponto central do Jansenismo, com o qual o grande escritor francês teve contato, embora o tenha renegado num determinado momento de sua vida.

Para melhor entender-se a obra Le Paysage, ou Promenade de PortRoyal des Champs, uma série de Odes que Racine dedicou a Port Royal, meu objeto de análise, farei um pequeno histórico sobre o Jansenismo, tentando mostrar como essa doutrina se propagou pela abadia de Port Royal des Champs, que, em razão disso, foi transformada em ruínas na época de Luís XIV. Atualmente, apresenta-se como um museu que guarda a memória dos jansenistas. Port Royal des Champs está situada no departamento de Yvelines, e não deve ser confundida com o antigo mosteiro da cidade de Paris, onde funcionam atualmente outras repartiçōes.

A abadia de Port Royal des Champs foi fundada em 1203 - assim denominada em razão do lugar em que foi criada: Porrois, (topônimo de origem celta), daí 'Portus Regius' (em latim), e Port Royal (em francês moderno) - e abrigava, nessa época, doze religiosas. Essa abadia de mulheres tornou-se, no século XVII, um baluarte do Jansenismo, local de reunião de grandes escritores, filósofos e teólogos.

Em 1602, Antoine Arnauld, advogado do Parlamento de Paris, pai de 20 crianças, conseguiu nomear uma de suas filhas, Jacqueline-Angélica, como abadessa de Port Royal, a qual não tinha senão onze anos. A abadia conhecera, então, um período de decadência; porém, quando Madre 
Angélica completou dezessete anos, ela resolveu restaurá-la e restabelecer a Regra Cisterciense na sua integridade. A partir de então, muitas mulheres da elite francesa foram se instalar na abadia, para ali viverem em profunda oração e na mais completa solidão. Entre elas encontravam-se Madre Inês, irmã da abadessa Madre Angélica; Madre Inês de Sainte-Thècle, tia de Jean Racine; Jacqueline, a irmã de Blaise Pascal, para citar apenas os nomes que nos interessam aqui. O lugar, porém, era úmido e insalubre, pelo fato de se situar numa região pantanosa; e em razão disso, em 1625, as religiosas se mudaram para Paris, tendo ali se instalado. Saint Cyran se tornou o diretor espiritual de Madre Angélica e, em 1636, foi ele quem introduziu, em Port Royal, o movimento jansenista.

Depois que as religiosas desocuparam Port Royal des Champs, os discípulos de Saint Cyran se instalaram em volta dessa abadia, em 1638, a fim de ali viverem na solidão, e em razão disso, foram chamados Solitários. Insensíveis às críticas, e sem apresentarem o menor ceticismo, os Solitários acreditavam que poderiam fundar um novo humanismo, pois acima de sua posição teológica, era o homem que estava em questão. Era um "novo homem" que aqueles intelectuais pretendiam promover; pedagogos de vanguarda foram os primeiros no século XVII a estabelecer um programa de estudos em língua francesa, tratamento do qual Racine tornou-se um dos primeiros beneficiários.

Além de administrarem trabalhos de saneamento e de drenagem, em Port Royal des Champs, os Solitários mandaram fabricar tamancos (como se sabe esse é o calçado que se usa em regiões úmidas) para os pobres, e abriram uma escola para meninos (Petites Écoles), onde Jean Racine fez seus primeiros estudos. Racine nasceu em 1639 (em La Ferté-Milon), e morreu em 1699, em Paris. Tendo ficado órfāo muito cedo, foi criado pela sua avó paterna (Marie des Moulins ou Desmoulins), cuja irmã (Suzanne) e sua filha (Agnès), eram religiosas em Port Royal. Mais tarde a avó para lá se retirou, também, levando o seu neto, que ali faria seus primeiros estudos. O jovem Racine freqüentou a escola elementar (Petites Écoles de Port Royal) de 1649 a 1658, onde lhe foi ministrado um ensino determinante para sua vida e sua carreira, que seria complementado com uma breve passagem pelo 
Colégio de Beauvais, e terminaria com um ano de estudos de Filosofia no Colégio de Harcourt, em Paris.

Em 1648, uma parte das religiosas de Paris retornou a Port Royal des Champs, tendo se instalado nos prédios restaurados pelos Messieurs 'Senhores' (os discípulos de Saint Cyran), e esses passaram a viver nas Granjas, que faziam parte do domínio da abadia. Foi nesse lugar - nas Granjas - que Jean Racine fez uma parte de seus estudos de Ciências Humanas (Humanidades).

Outra personagem renomada que habitou o mosteiro foi Blaise Pascal, o pensador, em companhia de outros intelectuais, os quais foram os principais Messieurs de Port Royal, tais como o teólogo Antoine Arnauld, o filho do fundador, mais conhecido como o Grande Arnauld (um dos autores da Gramática de Port Royal, juntamente com Arnaud Lancelot); Arnauld d'Andilly; Pierre Nicole; Jean Hamon; Antoine le Maîstre; Pierre Thomas du Fossé (autor de algumas hagiografias e de Mémoires 'Memórias', as quais Sainte Beuve muito elogiou, pelo fato de refletirem admiravelmente a vida de Port Royal); e ainda, Louis-Isaac Lemaîstre de Sacy; bem como muitas pessoas da nobreza francesa. Alguns daqueles nomes - sob a coordenação de Sacy - participaram da tradução da Bíblia de Port-Royal. Pelo fato de esses homens famosos, assim como todas as religiosas que ali viviam, terem abraçado o Jansenismo, a abadia foi perseguida por Luís XIV. Esse rei - insuflado pelos jesuítas, inimigos dos jansenistas - determinou, em 1669, a separação entre as duas abadias: Port Royal des Champs e Port Royal de Paris. Em 1705, não havia mais do que 25 religiosas na abadia, entre as quais, a mais jovem contava 60 anos. Elas foram condenadas pelo Vaticano, e obrigadas a se submeterem, isto é, assinarem o Formulário (o qual será referido mais adiante), sob pena de excomunhão. Em 1709, as religiosas foram levadas pela polícia (veja-se ilustração no apêndice) e dispersas em vários conventos; em 1710, os edifícios de Port Royal foram destruídos, as sepulturas violadas e os ossos colocados numa vala comum em Saint Lambert. 


\section{O que é o Jansenismo?}

Num primeiro sentido, o Jansenismo pode ser considerado como uma heresia que a Igreja de Roma condena em vários aspectos. Num sentido mais amplo, pode-se perceber que não é senão um movimento interno do Catolicismo, que rejeita as condenações impostas pela autoridade romana, e tenta apresentar uma imagem do Cristianismo, mais fiel às suas origens. (CARRAUD, 2008, p. 1) Apresenta-se como a interpretação fiel de Santo Agostinho sobre a Graça e a Predestinação, e caracteriza-se pela exigência de uma grande pureza, e de um certo rigor da prática religiosa. Assim nomeada por causa de seu iniciador, Cornelius Jansen, latinizado em Jansenius (como ficou mais conhecido), tal corrente religiosa e doutrinária conquistou vastas regiôes da Europa, e teve muitos partidários célebres, nos séculos XVII e XVIII. Jansenius tinha um discípulo e amigo na França - Jean Duvergier de Hauranne, o abade - que se tornaria Saint Cyran, a princípio, ele também jesuíta, até o momento em que se converteu ao Jansenismo e passou a ser, então, detestado pelos seus confrades. Porque ele se opunha à sua política, o Cardeal Richelieu mandou aprisioná-lo, e ao morrer dois meses depois de ter sido solto, Saint Cyran foi aclamado pelas multidóes, como um santo.

Contudo, a perseguição aos jansenistas se acentuou, quando Luís XIV subiu ao trono. Entre 1664-1669, os jansenistas foram obrigados a assinar um Formulário (Formulaire), que condenava o Augustinus, um tratado em latim, que havia surgido em 1640, e fora condenado pelo Papa, dois anos mais tarde. O Augustinus era baseado na doutrina de Santo Agostinho, e continha os principais preceitos do Jansenismo, sintetizado nas "Cinco Proposições”, que discutiam questôes de caráter teológico. Conhecido como Formulário de Alexandre VII, esse documento papal condenava as cinco proposições retiradas do Augustinus, obra teológica atribuída a Jansenius, tendo sido publicada depois de sua morte. Os religiosos e as religiosas de Port Royal deveriam, pois, estar de acordo com o Formulário, e assinar abaixo do seguinte texto: 
"Eu me submeto sinceramente à Constituição do Papa Inocêncio $\mathrm{X}$, de 31 de maio de 1653, segundo seu verdadeiro sentido, que determinou pela Constituição do nosso Santo Padre o Papa Alexandre VII, de 16 de outubro de 1656. Reconheço, que sou obrigado em consciência, a obedecer a essas Constituições, e condeno de coração e verbalmente a doutrina das Cinco Proposiçóes, de Cornelius Jansenius, contidas no seu livro intitulado Augustinus, que esses dois papas e os bispos condenaram, cuja doutrina não é exatamente a de Santo Agostinho, a qual Jansenius explicou mal, e é contrária ao verdadeiro sentido do [pensamento] desse santo doutor ". (In: CHANTIN, 1996, p. 24, tradução minha)

As religiosas de Port Royal des Champs que se recusaram a assinar o Formulário passaram a ser vigiadas, ficando impedidas de assistirem à missa e de receberem os sacramentos. O poder real pretendendo acabar com a abadia proibiu, em 1706, a eleição de uma nova abadessa, e em 1709, ordenou a dispersão das religiosas. Enfim, em 1711, Luís XIV mandou destruir a abadia, e acabar com a memória dos mortos de Port Royal, mandando dispersar as cinzas daqueles que ali descansavam. A opinião pública se sentiu profundamente tocada pelo fim dramático da abadia, cujas ruínas se transformaram, na época, em lugar de peregrinação dos jansenistas. Os seguidores de Jansenius resistiram até a exasperação, e esse fato foi considerado como uma das muitas causas que levaram à Revolução Francesa. $\mathrm{O}$ movimento jansenista começou a se extinguir, quando o Concordat de 1802, levou ao reagrupamento de todos os católicos franceses em torno do Papa. O texto do Concordat concedeu ao Cristianismo um lugar dominante na sociedade, e tentou, também, regularizar a desordem no seio da Igreja da França, a qual datava da época da Revolução. Napoleão percebera que a aliança com a Igreja Católica seria necessária para dissociar a causa da monarquia da religião à qual os franceses continuaram ligados. O regime concordatário foi, por outro lado, o que organizou as relaçôes entre as diferentes religióes e o Estado Francês, de 1801 a 1905, conforme o atesta o renomado teólogo, Bernard Ardura (ARDURA, 2001). 


\section{O jardim de Port Royal des Champs}

Segundo o medievalista francês, Jacques Le Goff, não existe um lugar de encontro mais importante entre o homem biológico e o homem social, do que o espaço. E o espaço é um objeto eminentemente cultural, variável ao gosto das sociedades, das culturas e das épocas, espaço orientado, impregnado de ideologia e de valores. (cf. LE GOFF, 1985, p. 62)

Um estudo sobre o jardim implica, antes, compreender este espaço cheio de simbolismos, tão caro aos escritores, já que a literatura de todas as épocas o tem utilizado como cenário. Desde o bosque, ou uma simples natureza rodeada de plantas, de árvores, de flores variadas e de aves canoras, de fontes e de riachos, que constituem um locus amoenus, ou até mesmo uma floresta, povoada por animais de toda espécie - selvagens ou não - esse topos tem merecido a atenção dos estudiosos de várias áreas, principalmente a dos literatos.

Nesse sentido, F. Chueca Goitia, o grande especialista espanhol em arquitetura, assevera que, no caso da jardinagem, a ordenação artificial segundo módulos geométricos ou mesmo imaginados de certos terrenos cultivados, com o objetivo de se obter um resultado estético, tem sido considerada como uma forma de criação artística, e em razão disso, tem atraído a atenção dos estudiosos. Da mesma forma, na literatura e na poesia, o jardim aparece como um motivo que pode chegar a sugerir o tema do harmoniosamente perfeito, de um lado, mas também, uma lamentável perda da relação entre o homem e a natureza, de outro, completa o especialista. Segundo Chueca Goitia, o jardim pode sugerir, também, uma metafórica projeção do subconsciente (sic). (cf. CHUECA GOITIA, 1973)

É, talvez, nesse último sentido, que se pode entender Racine se dedicando ao tema do jardim, mais precisamente, nas suas reminiscências de Port Royal: as Odes. Vivendo num século em que Ronsard e Boileau tornaram célebres o gênero, no sentido moderno - com suas odes majestosas e de sentimentos sublimes - tendo como principais características a elaboração estrófica, bem como a formalidade e a nobreza no tom e no estilo, Racine, da mesma forma, não deixaria de experimentar esse gênero, antes de se tornar o grande dramaturgo. 
As produções da juventude de Racine, entretanto, os primeiros ensaios de sua musa, não têm evidentemente a mesma qualidade de suas obras de dramaturgia. Um de seus críticos (L.R. sic) assevera que os versos das Odes são fracos, de conteúdo mais genérico, podendo se referir a todos os campos, e não particularmente a Port Royal. Mas, encontram-se nas Odes a Port Royal o "fogo" e a imaginação, observou ele. Trata-se de um jovem que sente prazer em descrever a solidão na qual vive, e o faz com perpétuas exclamaçóes no estilo de Malherbe e de Racan, completou o crítico do século XIX. (L.R., sic, 1820, p. 283, tradução minha)

Foi, portanto, bem no início de sua carreira, que Jean Racine, antes de vir a ser o grande dramaturgo francês, escreveu uma série de poemas intitulados Le Paysage, Promenade de Port Royal des Champs, compreendendo um total de sete odes, as quais apresentam um número variável de estrofes, compostas de dez versos cada uma, com predominância de octossílabos, possuindo métrica e rima variáveis. Obviamente, aqui tratarei de algumas odes apenas. A escolha incidiu, naturalmente, sobre aquelas que apresentam um locus amoenus. As "Odes a Port Royal", encontram-se em Obras Completas de J. Racine, Tomo IV, com notas dos comentadores, e foi publicada por L. Aimé-Martin, em Paris, junto ao livreiro Lefevre, em 1820 , sendo essa edição a que me serve como base neste estudo. Das "Sete Odes”, traduzi 14 estrofes sobre um total de 54, com predominância daquelas em que Racine descreve o jardim de Port Royal, por se tratar, obviamente, do tema que interessa aqui. Entretanto, para se entender a relação de Racine com Port Royal des Champs, torna-se necessário fazer uma breve referência aos outros temas das Odes, para melhor associá-los ao imaginário da abadia jansenista, lugar de suas lembranças mais remotas.

$\mathrm{Na}$ Ode Primeira, Racine apresenta, de maneira bastante ampla, um louvor a Port Royal - Louange de Port-Royal en général-conforme o próprio título indica, constituída de 7 estrofes, numa das quais - a primeira - ressalta um dos conceitos básicos do jansenismo, que é a questão da Graça Divina. Ele escreve: 
Santas moradas do silêncio,

Lugares de beleza e encantos cheios,

Porto, onde, no seio da paz,

Reinam a Graça e a Inocência;

Belos desertos que, rivalizando com os céus,

De seus tesouros mais preciosos

Cobriu a natureza.

Que assaz brilhante cor

Poderá traçar a pintura

De vosso adorado esplendor?

O fato de o vocábulo Graça estar grafado com letra maiúscula leva-nos a refletir sobre o seu significado no poema, pois, como foi dito acima, esse é um dos pontos mais discutidos da doutrina jansenista, sendo, na verdade, um conceito-chave, pois, Jansenius se inspirou nas convicçôes de Santo Agostinho, segundo o qual ninguém pode ser salvo sem a graça, a "graça eficaz", que é dada ou recusada por Deus. Porém, o teólogo belga foi além dos princípios do Santo de Hipona. Para Jansenius, o homem é atraído naturalmente para o mal, cultiva o amor por si mesmo, e não se volta senão para as questôes do prazer 'concupiscência'. Essa questão é tratada também por Pascal, que nas suas Pensées (1640), define as três concupiscências: a da carne (voluptuosidade), a do espírito (saber) e a da vontade (orgulho). Para Jansenius, essa busca do prazer é a causa da infelicidade do homem. Contudo, Deus enviou seu Filho para redimir os justos, aqueles que são contemplados com a graça, isto é, o deleite vitorioso. Essa graça desvia o homem do mal e o aproxima de Deus. A discussão teológica é longa e assaz eloqüente, os conceitos vão se entrecruzando com os filosóficos e se completando, no entanto, não há razão para discuti-los aqui.

A partir dessa estrofe inicial, Racine passa a descrever, nas Odes seguintes, um locus amoenus: uma lagoa, as flores, os frutos, em imagens sinestésicas, para as quais não economiza os adjetivos, características das odes, enquanto cantos de louvor.

$\mathrm{Na}$ Ode Segunda, composta de 9 estrofes, o poeta retrata a paisagem: Le paysage en Gros. Difícil ser insensível à atmosfera que envolve um lugar onde a harmonia parece ter sido feita para a contemplação e a meditação. 
A escolha de Racine não é arbitrária, pois, na realidade, são hectares de florestas, de terras agrícolas e de jardins circundando a abadia, na mais pura tradição cisterciense. Completam a paisagem arquitetural "Os Cem degraus", que na realidade são 109, e vão desde a abadia até às Granjas, nas quais se instalaram os Solitários. As religiosas faziam penitência e mortificação subindo os 109 degraus de joelhos. As Granjas foram construídas como extensão da abadia, em 1651, onde passaram a funcionar as Petites Écoles, atualmente, transformadas no "Museu Nacional das Granjas". Ali começaram as relações entre Racine e Port Royal, quando ele, tendo ficado órfão (perdeu a mãe aos dois anos, que morreu de parto, quando nasceu sua irmã, e o pai aos quatro anos), para lá foi levado pela sua avó paterna, conforme foi dito antes. Observemos o poeta evocando Port Royal como obra de Deus, descrevendo a religiosidade do lugar, aí associando seus "trabalhos e vigílias":

Vejo este sagrado santuário, Grande templo, santa morada

Onde Jesus a cada dia, ainda

Se imola, por nós, a Seu Pai.

Musa, é a Este Doce Salvador

Que devo consagrar meu coração,

Meus trabalhos e minhas vigílias:

É Dele o braço poderoso

Que fez todas estas maravilhas

Que tanto nos convidam e atraem.

[...]

$\mathrm{Na}$ referência ao claustro, na estrofe seguinte, pode-se imaginar a presença das religiosas em suas orações : "casto paraíso" (v. 5), "virgindade santa" (v.7), "mil anjos mortais" (v.8), "gemem aos pés dos altares" (v. 10). $\mathrm{O}$ "trono de lírio" pode referir-se tanto à pureza, no sentido de integridade moral - relacionada com a Graça Divina - como à monarquia francesa, uma vez que, a flor de lis é um dos símbolos históricos da França, pois afinal, o próprio Racine irá demonstrar, mais tarde, a sua simpatia pela realeza. Quanto ao "braço poderoso" de Cristo, na estrofe anterior, é bom 
lembrar que ele tem uma simbologia diferente para os jansenistas. Ele é representado com os braços para cima, diferentemente da tradição católicoromana, que o apresenta de braços abertos. ${ }^{1}$

Vejo este claustro venerado,

Os belos lugares do céu bem-amados,

Que com cem templos animados,

Escondem a riqueza adorada.

É neste casto paraíso

Que reina num trono de lírio,

A virgindade santa:

É lá que mil anjos mortais,

Com um eterno lamento,

Gemem aos pés dos altares.

$\mathrm{Na}$ estrofe que analisamos a seguir, há um vocábulo polissêmico, "vigílias" (v. 7), que tanto pode se referir às noites despertas - ou ainda, 'sentinela ou guarda durante a noite' - quanto à vigília espiritual, relacionada com os Salmos e os Evangelhos, significado mais provável no poema, se nos lembrarmos da seguinte passagem do Evangelho de SãoMarcos: "Vigiai, pois, visto que não sabeis quando o senhor da casa voltará, se à tarde, se à meia noite, se ao cantar do galo, se pela manhã, para que vindo de repente, não vos encontre dormindo. O que vos digo, digo a todos: vigiai!"(Marcos 13:35-37).

Sagrados palácios da inocência,

Astros vivos, coros gloriosos,

Que fazeis ver novos céus

Nestas moradas de silêncio,

Não, minha pena não pretende

Traçar aqui vossos combates,

Vossos jejuns e vossas vigílias:

Deve-se, para bem reverenciar

As esplêndidas maravilhas,

Ocultá-las (ou calá-las) e adorá-las.

${ }^{1}$ Devo essa informação ao meu colega Luiz Fernando Ferreira Sá, a quem agradeço. 
As lutas que tiveram de enfrentar as religiosas que abraçaram o jansenismo, assim como os eruditos que ali viveram, parecem ser evocadas a partir do quinto verso, sobre as quais o poeta prefere se "calar ou ocultá-las". Refirome às lutas ideológicas, é claro, embora as lutas dos jansenistas tenham sido também físicas, uma vez que as religiosas foram levadas à força da abadia de Port Royal, e alguns adeptos estiveram presos na Bastilha, como é o caso de Saint Cyran e de Sacy, para citar apenas os nomes já tratados aqui.

Na Ode Terceira, intitulada Description des bois, composta de 7 estrofes, há uma descrição dos bosques de Port Royal des Champs:

Estes velhos reinos das sombras,

Os grandes bosques, as negras florestas,

Quanta beleza e encantos escondem

Sob suas tão sombrias folhagens!

É nesta morada tranqüila

Que se vê reinar noite e dia

A paz e o silêncio;

É lá, dizem, que nossos ancestrais,

No século da inocência,

Saboreavam dos céus as delícias.

$[\ldots]$

Para se entender melhor essa passagem do poema é preciso lembrar que a abadia de Port Royal estava situada em uma planície, circundada por 150 hectares de terras plantadas, e 190 hectares de bosque. A fazenda da abadia foi desenvolvida em torno de um espaço retangular, sobre uma inclinação, possuindo um parque de 10 hectares, no qual havia um vinhedo, um pomar e um vergel. No jardim eram cultivadas peras e pavias, que Antoine d'Andilly enviava a Racine, quando esse já havia deixado Port Royal, talvez na esperança de que o poeta fosse condescendente com aquela abadia, onde fez seus primeiros estudos, e com a qual rompera relaçóes, quando se tornou, junto com Boileau, historiador oficial do rei Luis XIV.

$\mathrm{Na} O d e$ Quarta, intitulada L'Étang, composta de 8 estrofes, o poeta descreve a lagoa que circunda o lugar: 
Quão encantador é,

Ver esta lagoa graciosa,

Em que, como num leito precioso,

A onda é sempre calma e dormente !

Meus olhos, contemplemos mais de perto

Os inimitáveis retratos

Deste espelho úmido;

Miremos os encantos poderosos

Com que seu espelho líquido

Encanta e engana todos os sentidos.

[...]

$\mathrm{Na}$ Ode Quinta, Racine trata das pradarias - Lês Prairies - compostas de 7 estrofes. Nestes versos da quinta ode, percebe-se uma descrição mimética da natureza, porém, o poeta evoca a deusa dos jardins - Flora no seu palácio, o que coaduna com a sua formação clássica. Deusa das flores, dos jardins e da primavera, ela simboliza a primeira estação do ano, e costuma ser representada com uma coroa de flores, como, por exemplo, na sua estátua do jardim de Versalhes. A natureza descrita nesta ode evoca, por meio da deusa romana, uma estação maravilhosa para os europeus - na qual costuma ocorrer uma mudança de comportamento, uma "joie de vivre" cotidiana - e é o que parece refletir a partir daqui a pena do poeta: o libertar-se das suas inquietaçôes, relatadas nas odes anteriores. Nesta passagem, Racine faz uma espécie de prelúdio à beleza que se fará mais evidente nos versos da sétima ode, que serão analisados mais adiante.

Meu Deus! quantos encantos diversos

Nos apresentam as planícies charmosas,

Estes grandes prados tão verdes e belos,

Entre suas riquezas brilhantes!

Este doce ar, estes vivos odores,

O pomposo brilho destas flores

De que a erva se colore,

Não parecem dizer a nossos olhos

Que o palácio de Flora

Se encontra deveras nestes lugares?

[...] 
A Ode Sexta - Des troupeaux, et d'un combat de taureaux composta de 8 estrofes, descreve os rebanhos e um combate de touros. Esta passagem parece admitir outra leitura, além do sentido literal; talvez uma metáfora da condição humana, ou do destino do homem, lutas interiores ou ideológicas. Vejamos: "rebanhos errantes" (v. 2), provavelmente se referindo 'àqueles que não sabem de que lado se posicionar' nas lutas entre jesuítas e jansenistas, por exemplo, ou os partidários do rei; "roer os tesouros da pradaria" (v.4), pode sugerir 'danificar a natureza', por um lado, mas também desmoronamento e destruição do patrimônio de Port Royal (Luis XIV ao construir Versalhes mandou desviar as águas da região na qual se situava a abadia); com "dentes incertos" (v.7), que talvez possa ser descodificado como 'às escuras, sem um objetivo claro e definido ideologicamente'; e por fim, "os outros", certos do que fazer, ou de como agir ("Os outros, d'um passo certo", v. 8), vão beber nas boas fontes, isto é, nas "taças de prata", poderiam referir-se, provavelmente, àqueles que receberam a "Graça" do Onipotente:

É nestes campos floridos

Que se vê mil rebanhos errantes

Andando por cem lugares diferentes,

Roer os tesouros da pradaria:

Uns, encantados pelo seu aspecto,

Retiram com respeito

Seus dentes assaz incertos;

Os outros, d'um passo certo,

Vão beber nestas fontes.

Que parecem taças de prata.

[...]

Na realidade, esses versos de Racine parecem ser o eco do discurso de Madre Angélica de São João Arnauld d'Andilly, quando começou a dispersão das religiosas, que saíram de Paris para serem reconduzidas a Port Royal des Champs, no dia 3 de julho de 1663. Durante o trajeto, no qual ela encontrou as suas irmãs, que haviam sido dispersadas por outras abadias, Madre Angélica abriu a Bíblia numa página qualquer, como era costume 
em Port Royal des Champs, a fim de ver qual a mensagem de Deus, para elas, naquele dia. A eloqüência do seu longo discorrer, não deixa de ser interessante, após citar uma passagem do Livro de Jeremias: Vae pastoribus qui disperdunt et dilacerant gregem pascuae meae 'Ai dos pastores que dispersam e perdem as ovelhas do meu rebanho' $(\mathrm{Jr}, 23,1)$, pela afinidade semântica que apresenta com o texto de Racine, na estrofe acima citada:

(...) Poder-se-ia duvidar de que não houve Providência em tais encontros, e que se poderia ter feito a escolha no Antigo ou no Novo Testamento, de uma passagem que pode se aplicar, literalmente, a tudo que se passou na nossa comunidade, e agora, por ocasião de nosso retorno. Aí se vê uma comunidade numerosa, cercada por todo tipo da graça de Deus, e instruída pela verdade, figurada por um rebanho alimentado nas pastagens de Deus; os pastores que dispersaram sua união, e destruíram, o quanto puderam, seu espírito e sua disciplina, aí estão marcados por seu próprio nome; uma parte de nós, que foi dispersa entre várias casas, e a outra, que levaram, naquele dia, de nossa casa de Paris, estão claramente distintas; enfim, é impossível marcar mais inteligentemente e em termos mais positivos a reunião que Deus ia fazer naquele dia, e o nosso retorno à casa dos Campos [Port Royal des Champs], onde Deus começava a reunir os restos desse grande rebanho, ou seja, todas aquelas que escaparam de tantos perigos e tentações, por sua misericórdia, pela força de sua graça, que as tornou inquebrantáveis, e também, aquelas que tinham caído, por um tempo, sob o poder dos inimigos, e que foram arrancadas das mãos deles, pelo braço todo poderoso desse Bom Pastor, que não deixa perecer nenhuma de suas ovelhas, que o seu Pai lhe deu. (Vendredi 3 juillet 1665. Extrait de la Relation de captivité d'Angélique de Saint-Jean Arnauld d'Andilly, cf. LESAULNIER, 2009, p. 4, tradução minha)

Não é necessário lembrar aqui, que nos governos autoritários - e o do rei Luis XIV foi, não somente autoritário, mas também, absoluto - a dispersão dos grupos coevos é uma das primeiras medidas dos que se encontram no poder, indo numa direção contrária ao velho adágio de que "a união faz a força”. 
É na Ode Sétima - Les Jardins - que Racine irá descrever os jardins de Port Royal. Esses lugares devem trazer muitas doces lembranças ao poeta, pois era ali que as crianças das Petites Écoles brincavam, diariamente, durante o recreio, após a saída do refeitório, salvo quando chovia ou se fazia noite. O espaço era muito vasto, cheio de bosques e de pradarias, por onde caminhavam os mestres, sem perder de vista suas crianças. Cada mestre cuidava de cinco ou seis crianças. A pedagogia era moderna, não se aplicavam métodos violentos, eram proibidas agressōes às crianças. Os mestres de Racine foram ninguém menos, do que o grande helenista Claude Lancelot, um dos autores da Gramática de Port Royal, conforme dito anteriormente, Jean Hamon, que lhe ensinou italiano e espanhol; e Pierre Nicole, seu professor de latim. Sua cultura clássica se misturara com suas lembranças reais: as "pavias avermelhadas", uma espécie de pêssego antigo, as "maçãs douradas" da poesia greco-latina, os "damascos", concluindo num verso que não deixa dúvidas sobre isto: "fabulosas antigüidades". Neste encantado jardim não poderiam faltar as flores: a rosa vermelha, os lírios, a primeira significando, talvez, as paixões humanas, inflamadas de idéias - sabe-se que o século XVII foi uma época de pensamentos e idéias fervilhantes - e as últimas, os lírios - inicialmente símbolo mariano - contudo, ao ser relacionada com os francos, tornou-se, desde a Idade Média, um símbolo da realeza francesa.

Meus olhos, poderia em vós acreditar?

Estarei acordado? Vejo um jardim?

Não será algum sonho vão

Que me põe neste lugar de glória?

Vejo como novos céus

Onde mil astros deliciosos

Refletem sua luz,

E parece que nesta bela morada

A terra é herdeira

Daqueles que o dia afastou. 
Já, sobre esta rica entrada

Vejo as pavias avermelhadas

Espalhar os raios luzidios

De sua bela neve purpurada.

Deus! que prodígios inusitados!

Vejo nascer sobre os lírios

O encarnado da rosa,

Vejo a chama e seu avermelhado

Sobre a neve florida

Embelezar a própria brancura.

Vejo esta maçã cintilante,

$\mathrm{Ou}$ antes, este solzinho,

O doce damasco sem igual,

De cor tão tentadora.

Fabulosas antigüidades,

Já não exaltam as belezas

De suas maçãs douradas:

Vejo umas que, de um ouro gracioso,

Igualmente ornadas,

Encantam o gosto e os olhos.

Conheço a imponente matéria

Que podia sobre meus esboços sombrios

Lançar ainda os raios

De sua cintilante luz;

Mas a única tocha,

A mergulhar na água,

Já deu lugar às trevas;

E, por sua vez, as estrelas,

Como tochas fúnebres

Celebram o funeral do dia.

Ouço a inocente música

Das flautas e das clarinetes

Saudar a sombra nestes vilarejos

Com uma serenata rústica.

A sombra que, com seus doces sonos, 
Vem finalmente fazer aos trabalhos

Uma pacífica guerra,

Faz com que estes astros preciosos,

Que empalidecem sobre a terra,

Pareçam retornar aos céus.

As imagens que nos são apresentadas desse jardim ao entardecer, numa época de inverno, são belíssimas, parecem mesmo imagens de sonho, como o poeta se pergunta no terceiro verso da primeira estrofe: "Não será algum sonho vão (...)". O vermelho que se reflete nas "pavias" e na paisagem é o do firmamento. A natureza, em geral, se apresenta avermelhada, quando prenuncia um frio intenso; contudo, parece que no poema não se trata de um frio exterior apenas, mas sobretudo daquele frio que enregela a alma. Afinal, a relação de Racine com Port Royal, num determinado momento de sua vida, foi conflituosa. Trata-se aqui, na realidade, de um jardim completo, onde há flores, lírios brancos como a neve e rosas encarnadas; há frutos tais como as pavias avermelhadas, as maçãs cintilantes e os damascos, tudo isso num cenário de anoitecer, onde os astros brilhantes fazem lembrar o momento de se fazer uma pausa, pois, inicia-se, finalmente, a hora do descanso, depois de uma jornada de trabalho. Para completar a beleza desse locus de sonho e magia surge a música das flautas e clarinetes, provavelmente, um evento que se repete cotidianamente nas aldeias próximas ("vilarejos, serenata rústica", cf. última estrofe) encerrando a jornada de "trabalhos". Essa paisagem deslumbrante, descrita no momento do lusco-fusco, se assemelha a uma tela impressionista, apesar do anacronismo, já que Racine viveu dois séculos antes do movimento pictórico francês, que atingiria também as outras artes. Contudo, vaticinar é mister dos grandes poetas.

Fechando, aqui, a tradução e o estudo das Odes, resta acrescentar que diante deste jardim magnífico, descrito por Racine, não há mais o que dizer, a não ser sentir o cheiro das flores e o sabor dos frutos, e se possível, encontrar um pouco de paz, ou até mesmo sonhar, nesta Thebaïde, como chamou Madame de Sévigné, e que será o título de uma das tragédias do grande dramaturgo do século XVII francês. 


\section{Referências}

AIME-MARTIN, L. Oeuvres Complètes de J. Racine. Avec les notes de tous les commentateurs. Tome IV. Paris: Chez Lefevre Libraire, MDCCCXX.

ARDURA, B. Le Concordat entre Pie VII et Bonaparte, 15 juillet 1801. Paris: Le Cerf, 2001.

CARRAUD, V. Conférence de présentation du jansénisme, disponible par ailleurs sur le site de l'Eglise réformée d'Auteuil. In: Publications de la Société des Amis de Port-Royal, 2008.

CHANTIN, J.-P. Le jansénisme. Entre hérésie imaginaire et résistance catholique. Paris: Le Cerf, 1996.

CHUECA GOITIA, F. Breves considérations sur les jardins-vergers de l'Espagne musulmane. In: Actes du 2ème Colloque International sur la protection et la restauration des jardins historiques. (ICOMOS - IFLA - Grenade, Espagne, 29 oct. - 4 nov. 1973.

LE GOFF, J. O maravilhoso e o quotidiano no Ocidente Medieval. Lisboa: Ed. Setenta, 1985.

LESAULNIER, J. La vie quotidienne à l'Abbaye de Port Royal III. De Paris à Port-Royal des Champs.Vendredi le 3 juillet 1665. Extrait de la Relation de captivité d'Angélique de Saint-Jean Arnauld d'Andilly, In: Bibliothèque électronique de Port-Royal, 2009.

ORCIBAL, J. Qu'est-ce que le jansénisme? Cahiers de l'Association Internationale des Études Françaises, n. 3 - 4 -5, juillet 1953, p. 39-53.

ORCIBAL, J. Chroniques de Port-Royal, 26-27-28, (1977-1978-1979), p. 7-13. In: Actes du Colloque organisé par la Société des Amis de Port-Royal sur "les deux abbés de Saint-Cyran». Château d'Azayle-Ferron les 6-8 octobre 1978.

ORCIBAL, J. Le Jansénisme, Saint-Cyran et Barcos. In: Bibliothèque électronique de Port-Royal, 2008, troisième série, $\mathrm{n}^{\circ} 8$.

RACINE, J. Le Paysage, ou Promenade de Port-Royal des Champs. In: Oeuvres Complètes de J. Racine. Editada por L. AIME-MARTIN, Tomo IV. Paris: Chez Lefevre, Libraire, MDCCCXX. 


\section{Apêndice}

RACINE, J. LE PAYSAGE, OU PROMENADE DE PORT-ROYAL DES CHAMPS

Série d'odes composées en 1655 par le bon élève des «Petites Écoles» de Port-Royal.

[Todas as Odes aqui analisadas foram traduzidas por $\mathrm{mim}^{2}$ ].

Ode Primeira

1

Santas moradas do silêncio,

Lugares de beleza e encantos cheios,

Porto, onde, no seio da paz,

Reinam a Graça e a Inocência;

Belos desertos que, rivalizando com os céus,

De seus tesouros mais preciosos

Cobriu a natureza.

Que assaz brilhante cor

Poderá traçar a pintura

De vosso adorado esplendor?

$[\ldots]$

7

A natureza é inimitável;

E quando está em liberdade,

Brilha com uma claridade

Tão doce quão verdadeira.

É ela que, sobre estes valejos,

Bosques, prados e sulcos,

Assina seu poder;

É ela que com suas belezas,

${ }^{2}$ Meus profundos agradecimentos à Professora Dra. Annick Moreau, da Université de Poitiers, França, tradutora renomada das línguas francesa e portuguesa, pela sua acurada releitura de minha tradução. 
Sem a inocência ofender

Encanta nossos olhos.

$[\ldots]$

Ode Segunda

4

Vejo este sagrado santuário,

Grande templo, santa morada

Onde Jesus a cada dia, ainda

Se imola, por nós, a Seu Pai.

Musa, é a Este Doce Salvador

Que devo consagrar meu coração,

Meus trabalhos e minhas vigílias:

É Dele o braço poderoso

Que fez todas estas maravilhas

Que tanto nos convidam e atraem.

$[\ldots]$

6

Vejo este claustro venerado,

Os belos lugares do céu bem-amados,

Que com cem templos animados,

Escondem a riqueza adorada.

É neste casto paraíso

Que reina num trono de lírio,

A virgindade santa:

É lá que mil anjos mortais,

Com um eterno lamento,

Gemem aos pés dos altares.

7

Sagrados palácios da inocência,

Astros vivos, coros gloriosos,

Que fazeis ver novos céus

Nestas moradas de silêncio,

Não, minha pena não pretende

Traçar aqui vossos combates,

Vossos jejuns e vossas vigílias: 
Deve-se, para bem reverenciar

As esplêndidas maravilhas,

Calá-las e adorá-las.

[...]

Ode Terceira

1

Estes velhos reinos das sombras,

Os grandes bosques, as negras florestas,

Quanta beleza e encantos escondem

Sob suas tão sombrias folhagens!

É nesta morada tranqüila

Que se vê reinar noite e dia

A paz e o silêncio;

É lá, dizem, que nossos ancestrais,

No século da inocência,

Saboreavam dos céus as delícias.

[...]

Ode Quarta

1

Quão encantador é,

Ver esta lagoa graciosa,

Em que, como num leito precioso,

A onda é sempre calma e dormente!

Meus olhos, contemplemos mais de perto

Os inimitáveis retratos

Deste espelho úmido;

Miremos os encantos poderosos

Com que seu espelho líquido

Encanta e engana todos os sentidos.

[...]

Ode Quinta

1

Meu Deus! quantos encantos diversos

Nos apresentam as planícies charmosas,

Estes grandes prados tão verdes e belos, 
Entre suas riquezas brilhantes!

Este doce ar, estes vivos odores,

O pomposo brilho destas flores

De que a erva se colore,

Não parecem dizer a nossos olhos

Que o palácio de Flora

Se encontra deveras nestes lugares?

$[\ldots]$

Ode Sexta

1

É nestes campos floridos

Que se vê mil rebanhos errantes

Andando por cem lugares diferentes,

Roer os tesouros da pradaria:

Uns, encantados pelo seu aspecto,

Retiram com respeito

Seus dentes assaz incertos;

Os outros, d'um passo certo,

Vão beber a estas fontes.

Que parecem taças de prata.

[...]

Ode Sétima

1

Meus olhos, poderia em vós acreditar?

Estarei acordado? Vejo um jardim?

Não será algum sonho vão

Que me põe neste lugar de glória?

Vejo como novos céus

Onde mil astros deliciosos

Refletem sua luz,

E parece que nesta bela morada

A terra é herdeira

Daqueles que o dia afastou. 
Já, sobre esta rica entrada

Vejo as pavias avermelhadas

Espalhar os raios luzidios

De sua bela neve purpurada.

Deus! que prodígios inusitados!

Vejo nascer sobre os lírios

O encarnado da rosa,

Vejo a chama e seu avermelhado

Sobre a neve florida

Embelezar a própria brancura.

3

Vejo esta maçã cintilante,

$\mathrm{Ou}$ antes, este solzinho,

O doce damasco sem igual,

De cor tão tentadora.

Fabulosas antigüidades,

Já não exaltem as belezas

De suas maçãs douradas:

Vejo umas que, de um ouro gracioso,

Igualmente ornadas,

Encantam o gosto e os olhos.

8

Conheço a imponente matéria

Que podia sobre meus esboços sombrios

Lançar ainda os raios

De sua cintilante luz;

Mas a única tocha,

A mergulhar na água,

Já deu lugar às trevas;

E, por sua vez, as estrelas,

Como tochas fúnebres

Celebram o funeral do dia. 
9

Ouço a inocente música

Das flautas e das clarinetes

Saudar a sombra nestes vilarejos

Com uma serenata rústica.

A sombra que, com seus doces sonos,

Vem finalmente fazer aos trabalhos

Uma pacífica guerra,

Faz com que estes astros preciosos,

Que empalidecem sobre a terra,

Pareçam retornar aos céus.

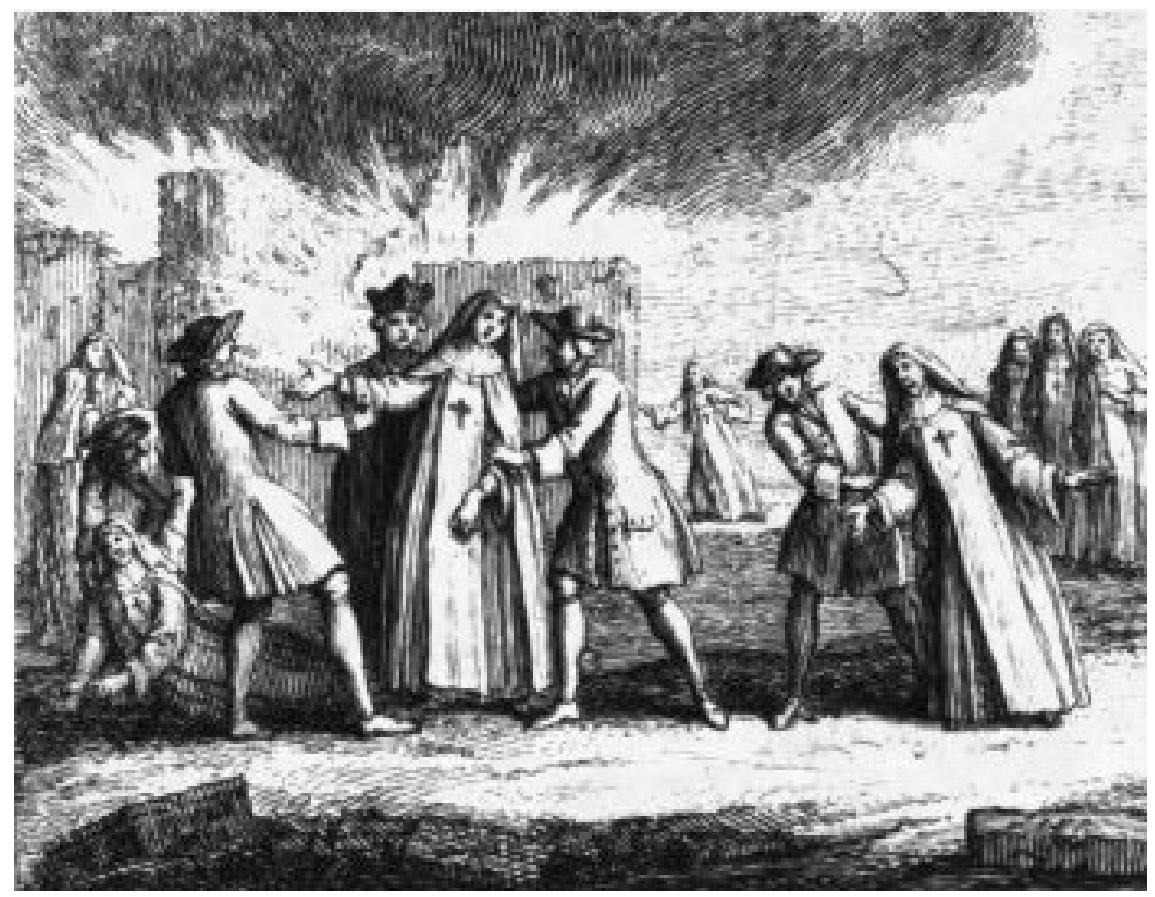

Em 1709, as religiosas de Port Royal foram levadas pelos comissários de polícia e dispersas em vários conventos, como mostra a ilustração acima. 


\section{Resumo}

Este trabalho apresenta uma tradução, seguida de uma análise de 14 estrofes, das 54 que compóem as 7 Odes a Port Royal, de Jean Racine. Focalizando o locus amoenus, procura relacionar o texto do grande dramaturgo francês com o contexto histórico evocado nos poemas, particularmente com o jansenismo.

\section{Résumé}

Ce travail présente une traduction suivie d'une analyse de 14 strophes sur les 54 qui composent les 7 Odes à Port Royal de Jean Racine. En se concentrant sur le locus amoenus, on essaye d'établir un lien entre le texte du grand dramaturge français et le contexte historique évoqué dans les poèmes, en particulier avec le jansénisme. 